\title{
BUSINESS-ORIENTED RESEARCH PROFESSIONALS - EMPIRICAL RESULTS FOR ACADEMICS' INTERDISCIPLINARITY AND THEIR COLLABORATION WITH ENTERPRISES ${ }^{2}$
}

\begin{abstract}
Summary
The aim of the paper is to present profiles of scientists and research professionals who perform activities in favour of business. Characteristics of academics with reference to their scientific achievements, professional recognition and scientific interdisciplinarity are presented.

Profiles are created on the basis of analyses of empirical results collected from the survey taken among academic society. It is possible to compare profiles of researchers working for business sector to these who are eager to cooperate with companies. Characteristics concerning individual scientists refer to their age, gender, scientific degree and affiliation, together with the discipline in which they perform their scientific activities.

The following study is the part of the project aimed at investigation of Polish scientific community, with reference to interdisciplinarity in research fields and performance of Polish scientists. Analyses have been focused on studying relations between interdisciplinarity of research and successes of Polish scientists achieved at national level. The core idea of the given analyses is to identify and try to measure relations between business and scientific activities.

It is suggested that academics collaborating with enterprises are producing more voluble research and publications. These scientists are also appreciated as scientific professionals by academic society. Finally, researchers supporting enterprises with scientific knowledge and expertise present higher level of interdisciplnarity in their research.
\end{abstract}

Key words: entrepreneurial scientists, business-oriented researchers, interdiscpilnarity

\section{Introduction}

Science and innovation policies at global and national levels are aimed at supporting scientific activities for business purposes and strengthening entrepreneurial university activities. In particular, it concerns implementation of science-business support actions

\footnotetext{
${ }^{1}$ Izabela Kijeńska-Dąbrowska, Ph.D. - National Information Processing Institute, e-mail: izabela.kijenska@ gmail.com. Marek Młodożeniec, M.Sc. - National Information Processing Institute, email: marek.mlodozeniec@, opi.org.pl

2 The work presented in this paper has been supported by project "Interdisciplinarity in research with reference to scientific performance of individual researchers" National Science Centre grant No 2013/09/D/HS4/02729 and statutory founding from the Information Processing Institute, public research institute financed by the Ministry of Science and Higher Education, Poland.
} 
for engaging Triple Helix (TH) linkage between science and economy for innovation creation in favour of the research results commercialisation.

The notion of the "entrepreneurial university" has been present and evaluated in literature for the last twenty-five years [e.g. Clark 1998; Etzkowitz 2004; Lehrera et al., 2009]. In the case of Polish scientific environment it should be extended to the term "entrepreneurial research entity". It is caused by the fact that more than $95 \%$ of the research activities, both curiosity-driven and performed for the commercialisation purposes are conducted by public research entities. Specific combination of units acting within the R\&D sector in Poland consists of three types of public research centres, in particular higher education units (HEUs), public research centres (PR\&D) and institutes of Polish Academy of Science (PAS), [Kijeńska-Dąbrowska, 2011], together with a new type of private research companies.

Specific characteristics of the research environment in Poland enables to analyse jointly attitude of professionals conducting scientific research activities and working in each type of research entity. Thus terms: scientists, researchers and academics are used as synonyms in the paper. National policy toward science and innovation generally refers to scientists and research professionals, not depending on the type of research entity, unless it is defined as research or academic centre [Science Funding Act, 2010; Higher Education Act, 2005]. The notion applied in the paper can also be supported by the fact that entrepreneurial concept embraces universities and public R\&D entities of all types, including these with a strong research tradition and those that are newly created by the market needs [Mohrman et al., 2008]. Finally, the literature on TH model of partnership cover three actors - government, industry and higher education [Etzkowitz, Leydesdorff, 2000; Etzkowitz, 2008; van Vught et al., 2010; Kim et al., 2012] and does not require obligatory structuring for different types of research entities that embrace similar activities as academic units.

It is of great importance for the economy and policy makers to learn the characteristics of researchers that are eager to conduct research in order to create new solutions to problems encountered by companies. It refers not only to technical, but also to nontechnical problems that may occur during business performance. The contemporary scientific developments in various disciplines can be transferred into practical solutions adopted in companies. The technology, or specialist knowledge transfer, is no longer limited to technical and engineering disciplines. Thus analyses of researchers profiles in vast range of disciplines engaged in various types of entities and different scientific experience is required. The profiling procedures may result in stating suggestions for possible intervention for authorities or new strategies creation in the area of promoting knowledge based innovativeness.

For the purposes of the paper, entrepreneurial researchers are defined as those with positive attitude toward and experience in individual collaboration with companies. On the contrary, researchers with negative attitude toward and no experience in research for commercialisation purposes are set.

The pressure on commercialisation of academic know-how, together with the need of enhancing technology transfer process of knowledge created in academia, is of great importance for knowledge-based economies and for knowledge-based innovation 
growth [Cook et al., 2008; Collier, Gray, 2010; Leydesdorff, Meyer, 2003; Hagen, 2008; Philpott et al., 2011].

There is visible change in the paradigm of research entities. Pure knowledge and research based involving individual curiosity based excellence is slowly replaced by societally shared knowledge based excellence [Gibb et al., 2012, p. 5]. With reference to individual academic activity within the process of innovation creation, it is expected for research professional to be prepared to engage in the transforming pure research results into commercial exploitation [Agraval, 2001].

Consequently, individual scientist should be eager to cooperate closely with the customer that is interested in application of research results. Profiling research professionals with reference to their will and ability to work on new commercial innovations in collaboration with business sector is at present of interest for social and economic scientists.

Studies on entrepreneurial behaviour of individual academics concentrate on subjects relating to different understanding of this attitude and various types of academic entrepreneurial performance [Bird, Allen, 1989; Duberley et al., 2007; Meyer, Evans, 2007; Mosey et al., 2012; Van Looy et al., 2011; D’Este, Perkmann, 2010]. Recent empirical studies on profiles of successful Polish entrepreneurial researchers focus on their scientific background and excellence [Knapińska, Tomczyńska, 2013]. In the paper presented here, the emphasis is placed on the vast range of criteria describing the entrepreneurial academics features and their attitude toward supporting business with knowledge based applications. Analyses presented embrace in a contemporary trend of empirical studies on profiling scientists with its exceptional and unique approach.

The notion of scientific interdisciplinarity is taken into the study as it refers to the idea of new knowledge and new technologies (innovations) creation. Many empirical studies prove that interdisciplinary research leads to innovative outcomes based on several scientific areas (multi-technology products), [Leydesdorff, 2007, Leydesdorff, Rafols 2011]. Additionally relations between actors taking part in the knowledge creation process, in particular academia, industry and public (consumers), shape the boundaries and definitions of existing scientific disciplines [Meyer, Rafols, 2010]. These boundaries are dynamic and constantly changing. New knowledge and innovations lead to emerging new markets, but at the same time they have the effect of emerging new scientific disciplines.

\section{Research methodology and results}

The idea of the study started from the question whether and to what extend collaboration between scientists and entrepreneurs is related to publication performance and peer-reviewing activities of research professionals. It has been expected that there is a positive correlation between collaboration activities and number of publications and number of peer-to-peer reviews.

Additionally, the second issue concentrates on whether the academics' collaboration with enterprises is related to professionals' scientific interdisciplinarity. It has been 
expected that scientists with experience in business collaboration present higher level of scientific interdisciplinarity. While interdiscpinality might be defined as extending the scope of research interests and research over more than one scientific discipline, one can measure the level of interdisciplinarity using appropriate indicators.

Presented study is based on the on-line survey conducted in September-December 2013 by the National Information Processing Institute (NIPI) research centre among more than 54000 research professionals registered in the Polish Science Database. The primary analysis was aimed at the reviewing Polish scientific environment, whether or not it supports knowledge-based innovativeness (i.e. based on scientific achievements), thus the analysis was entitled Knowledge-Brokering Survey. Obtained database covered initially responses of $\mathrm{N}=14082$ Polish research professionals. The response rate reached the level of $24.8 \%$. Data gathered from the on-line survey has been supplemented with respondents' demographic characteristics from the „Ludzie Nauki” (Research Professionals) database: http://www.nauka-polska.pl/Ludzie-nauki.html. The database is administrated and processed by the NIPI. The demographic features of respondents taken into consideration concerned: gender, age, scientific degree and scientific discipline of origin, affiliation, together with number of publications and registered peer-to-peer reviews. Due to uncompleted information and missing values the initial number of observation from the Knowledge-Brokering Survey has been decreased to the level of $\mathrm{N}=13727$. All statistical analyses and calculations have been performed in $\mathrm{R}$ software environment.

The Propensity Score Matching (PSM) statistical technique on original data was used for secondary analysis in order to measure direct effect of academic collaboration with enterprises on their performance.

Secondly, analysis of the Stirling Index (SI) values set for scientific performance of individuals was conducted in order to measure correlation between academic's interdisciplinarty and individual's experience in business-oriented performance.

\subsection{Propensity Score Matching Analysis}

The first step of analysis of research professionals registered in the processed database concerned a simple comparison between average numbers of publications and reviews of respondents replying positively or not to the question concerning experience in business collaboration. Results of this comparison are presented in Table 1.

This comparison gives only preliminary findings. The two compared groups are highly differentiated. Number of observation in each group of scientists is not equal. According to the analysis, researchers collaborating with enterprises are on average older and have higher scientific degrees than scientists with no experience in working with business. At the same time, older researchers are those having greater numbers in both categories: papers and peer reviews. It is also visible, that academics collaborating with business are represented mostly by males. Majority of them work in public research centres and act in the field of technical and engineering disciplines. The differences in demographic characteristics of researchers are presented on Chart 1. 
TABLE 1. Average number of publications and reviews according to the experience in business collaboration

\begin{tabular}{|c|c|c|}
\hline $\begin{array}{c}\text { Question: } \\
\text { Do you have experience in } \\
\text { collaboration with } \\
\text { enterprises on solving } \\
\text { technical issues? }\end{array}$ & $\begin{array}{c}\text { Average } \\
\text { Publications No }\end{array}$ & $\begin{array}{c}\text { Average } \\
\text { Peer-to-Peer Reviews No }\end{array}$ \\
\hline No $(\mathrm{N}=7921)$ & 15.75 & 1.49 \\
Yes (N=5806) & 25.26 & 1.79 \\
Average difference & 9.51 & 0.30 \\
\hline (collaboration "gross effect") & & \\
\hline
\end{tabular}

Source: author's own work.

CHART 1.

Structure and demographic characteristics of academics collaborating and non-collaborating with enterprises

RESEARCHERS NOT COLLABORATING

WITH ENTERPRISES ( $\mathrm{N}=7921)$

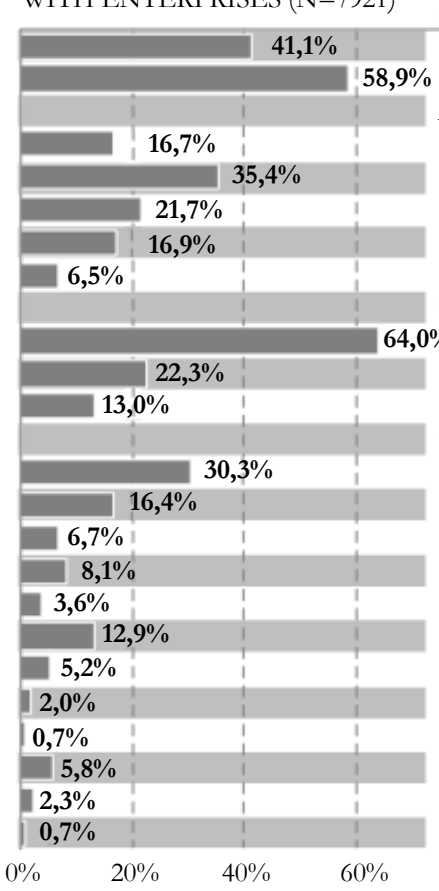

GENDER

male

female

AGE

under 35 years

35-44 years

45-54 years

55-64 years

65 years and more

SCIENTIFIC DEGREE

Dr

Dr hab.

Prof.

SCIENTIFIC DISCILPLINE

humanities

economic and social science science

biological science

natural science

medical science

agricultural science

mechanics, technical engineering

material engineering

chemical science

electronics, communication and IT

mining and energy studies

$80 \%$
RESEARCHERS COLLABORATING WITH

ENTERPRISES $(\mathrm{N}=7921)$

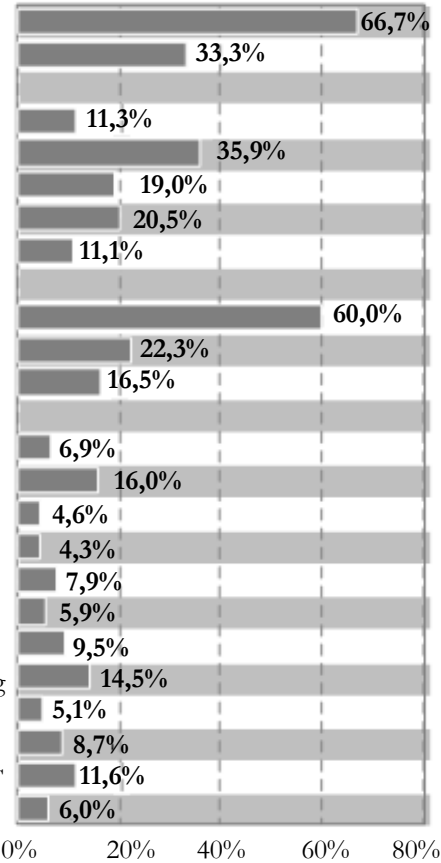

Source: author's own work. 
Differences in demographic characteristics are likely to affect average numbers of publications and peer-to-peer reviews of individuals. Therefore, direct comparison between groups, visible on Chart 1, is not proper. It does not confirm influence of academic's business collaboration on publishing or peer-to-peer reviewing of individuals. The scale of the influence is unknown due to structural differences in analysed groups of researchers.

Propensity Score Matching (PSM) is a sophisticated quasi-experimental statistical technique, which allow comparing mean scores within two groups, that differ in existence of a single experimental factor (experimental and control group). The difference in demographic structure of these groups, which may affect the simple mean scores comparison, is thus minimized.

Observed differences in average numbers of publications and peer-to-peer reviews in groups determined by value of independent factor (presence/absence of collaboration), given in Table 1, are described as collaboration "gross effect". The "net effect" of collaboration with enterprises on individual's achievements, the intrinsic influence of this collaboration on scientist' performance need to be refined in accordance with the given equitation:

\section{gross effect $=$ net effect $(\approx$ casual effect $)+$ effect of structural differences in compared groups of observations}

The aim of the study was to measure direct influence of collaboration/no-collaboration with enterprises on individual's achievements understood as publications and peer-to peer reviews numbers. It was needed to compare achievements of individuals (described as dependent variables) being under the influence of existing independent factor (described as collaboration with business sector). The value of this independent factor can only have two variables. Scientists either have or have not experience in collaboration with enterprises. Thus, the collaboration activity was defined as a single experimental factor differentiating groups of researchers.

Propensity Score Matching (PSM) allows comparing mean scores within two groups, that differ in a presence of a single experimental factor (experimental and control group). The difference in demographic structure of these groups, which may affect the simple mean scores comparison, is thus minimized by drawing from control group a sample of "best matche" or "sibling" for all cases from experimental group (i.e. cases that match their demographic profile). Several statistical techniques are used to create the so-called "reference group", consisting of "siblings" and thus having structure similar to experimental group. The comparison of index mean scores between experimental and reference group is called "net effect". This represents intrinsic effect of an experimental binary factor on key index, as opposed to "gross effec" gained from comparison between experimental and control group, which may be highly affected by their demographic divergence.

PSM procedure requires calculating logistic regression, where experimental binary factor (i.e. having (or not) experience in collaboration with enterprises) is a dependent variable, and all variables that might interfere in inquired influence (mainly demographics) 
acts as predictors. The presence of collaboration performance was set as value 1 , while the lack of this activity was set to value 0 . All accessible and registered in given databases information concerning individual scientists was used as independent variables (predictors) for the regression model. In particular following data concerning academics was taken into consideration:

- gender,

- $\quad$ age (in total number),

- $\quad$ scientific degree (4 categories: MSc; Dr; Dr hab.; Professor),

- $\quad$ single scientific discipline of origin (12 categories: humanities; economic and social sciences; science; biological sciences; natural sciences; medical sciences; agricultural sciences; mechanics, technical engineering and architecture; materials science; chemical sciences; electronics, communications and IT; mining and energy studies),

- $\quad$ type of research entity given as affiliation (public research centre, institute of PAS, higher education unit, private enterprise, medical unit and others),

- geographic origin of research entity at which scientists is affiliated (region/ voivodeship).

The final regression model used 37 independent variables ${ }^{3}$. Constructed model was statistically significant (Cox \& Snell $\mathrm{R}^{2}=0.233$; Nagelkerke $\mathrm{R}^{2}=0.313$;

$\mathrm{p}<0.001$ ), which states the significance of observed dependence. Most of chosen predictors were found as statistically significant. Exceptions concern: two scientific degrees (Dr hab, Prof), affiliation in Institute of PAS or medical unit and geographic origin of affiliation.

Applied in the study procedure of PSM used nearest neighbour method, as simplest and most common technique. There was no risk of inaccurate matching in the analysis, as the number of observations in reference group was considered high. Nearest neighbour method applies simple algorithm: each case from experimental group was matched with similar case drawn from that control group. Matched pairs have identical (or if there is none - at least nearest) value of their Propensity Score as its own value ("best match"). Each of 5806 cases from the experimental group (collaborative academics) was matched with at least one of 7921 cases from control group (notcollaborative academics). Matching procedure was based on PS values (most similar cases). If there was more than one "best matches" available within control group, all these $\mathrm{k}$ cases were matched as one, with their weights set on $1 / \mathrm{k}$. As a result, reference group is created, consisting of all cases drawn from control group as "best matches". The best matches cases constitute the reference group prepared for further analysis.

The quality of matching procedure was evaluated by the similarity of Propensity Score values for pairs of chosen cases. This condition was satisfied. Linked scientists (from reference and control groups) have the same gender, age, scientific degree and even do research in the same field. Potential differences might only concern external factors but due to adequate matching their effect in this analysis was minimalized. The mean distance on PS between two matched cases equals $0.0057 \%$ while the maximum difference at

\footnotetext{
336 instrumental binary variables and one continuous variable (age)
} 
which cases were matched was $0.9257 \%$. More than two thirds of matched pairs covered cases with exact values of Propensity Scores. These parameters provide an evidence for precisely fitting of matching procedure.

\subsection{Stirling Index Analysis}

Database of scientists created and processed for the purposes of the Propensity Score Matching procedures assessing impact of collaboration/not-collaboration with enterprises on academics' scientific performance $(\mathrm{N}=13727)$ was used as the reference for the analysis of Stirling Index values.

Interdisciplinarity in scientific performance of research professionals focused on the individual's ability to successfully do research in at least two separate research fields. This success might be evidenced by number of gained external grants for projects conducted in different scientific disciplines.

The applied concept assumed that successful scientists are those, who are prone to apply for external funding for their studies. Only leading, and considered as promising, research projects are accepted for such financing. The content of each research proposal is subject to evaluation of scientific significance, reasonable financial outlay, expectations concerning research results and value added to the state of knowledge. That concept thus guarantees, that academics working in research projects (accepted for external funding) from various disciplines are more likely to be interdisciplinary in their expertise.

With reference to the definition of interdisciplinarity used, the population of Polish research professionals applying successfully for external funding from the National Science Centre (NSC), Poland was considered as a source for potentially interdisciplinary researchers. According to the NSC schemes, funding grants are awarded in 25 separate scientific disciplines classified in three research fields (panels of disciplines): Arts, Humanities and Social Sciences, Physical Sciences and Engineering and Life Sciences. Complete list of the disciplines is presented in Appendix 1. Data sources used for the analysis cover research proposals accepted for financing in period 01.201105.2014. The processed database of NSC grants include information on $\mathrm{N}=4123$ scientists who have been involved at least at two research projects either from single discipline or several research areas.

The next step of database preparation involved comparing number of individual cases that are both present in the database of potentially interdisciplinary researchers and the Knowledge-Brokering Survey. At this stage the number of N=2076 individual researchers complied with the criteria. Information describing these cases formed the database for measuring research interdisciplinarity of academics.

Indicators measuring research interdisciplinarity of individuals need to take form of a scientific disciplines distribution function. The highest level of interdisciplinarity should be reserved to scientists that do research in each of the enumerated scientific disciplines. In the case of the projects performed within the NSC schemes, project can be assigned to one of twenty-five scientific disciplines, thus the most interdisciplinary researchers would be these attaining twenty-five grants in twenty-five disciplines. The 
distribution function of such constructed interdisciplinarity indicator takes the form of the vector of frequencies: $\left\{\mathrm{p}_{1}, \mathrm{p}_{2}, \ldots, \mathrm{p}_{25}\right\}$, and the sum of frequencies is equal to one $\left(\mathrm{p}_{1}+\mathrm{p}_{2}+\ldots+\mathrm{p}_{25}=1\right)$.

The Stirling Index was chosen to measure research interdisciplinarity amongst academics performing studies within the NSC grants. The SI is one of the common and simple measures used for determining similarities and/or disparities between scope areas of the research projects, papers or individuals' research fields. This indicator can also be used to analyse weather subject areas of two projects or two papers are similar or different. This indictor enables visualisation of the interdisciplinary/non-interdisciplinary research performance. It can be also used for comparison of interdisciplinarity levels between groups of researchers [Leydesdorff, Rafols, 2011].

The IS formula applied in the study has the form of equitation:

$$
\mathrm{SI}=\sum_{\mathrm{i}=1}^{\mathrm{k}} \sum_{\mathrm{j}=1}^{\mathrm{k}} \mathrm{d}_{\mathrm{ij}} \cdot \mathrm{p}_{\mathrm{i}} \cdot \mathrm{p}_{\mathrm{j}}
$$

where $\mathrm{d}_{\mathrm{ij}}$ states the distance measure between pair $\{\mathrm{i}, \mathrm{j}\}$ of scientific disciplines. The value of $\mathrm{d}_{\mathrm{ij}}$ represents the binary relation on set of 25 disciplines enumerated by the NSC. Thus the values range is $\mathrm{d}_{\mathrm{ij}}=1$, in case of projects from separate disciplines, and $\mathrm{d}_{\mathrm{ij}}=0$, in case of projects from the same discipline.

For the present study it was also needed to distinguish research interdisciplinarity within one research field (discipline panel) from research disciplinary over two research fields. Interdisciplinarity within single research field ought to be valued less than interdisciplinarity existing over two discipline panels. Finally, it was decided that distance measure between two disciplines would be doubled if disciplines derive from different discipline panels $\left(\mathrm{d}_{\mathrm{ij}}=2\right)$. In the set conditions the Stirling Index can attain values in the range $\left\langle 0 ; 1 \frac{1}{3}\right\rangle$. The higher is the value of the indicator, the more distant are scientific disciplines and the higher interdisciplinarity of one's performance.

\section{Results and interpretation}

\subsection{Propensity Score Matching Analysis}

As a result of the applied PSM procedure, the reference group of academics not collaborating with enterprises was created. This group of scientists from reference group have similar demographic profile as scientists from experimental group (i.e. scientists collaborating with enterprises). As it is visible on Chart 2, the structure of reference group is much alike that of the experimental group. The minor differences presented are unavoidable residual of primary contrast between the groups and might be tolerated as not statistically significant. They do not have impact on different patterns of publishing or reviewing performance between experimental and reference groups.

The demographic disparity between groups of collaborating and not collaborating scientists was kept to its minimum. The only known factor contrasting both groups, and therefore the most likely cause of differing publication productivity and peer-to- 
peer reviewing performance, is the presence or absence of experience in collaboration with enterprises.

CHART 2.

Structure and demographic characteristics of academics non-collaborating and collaborating with enterprises (reference and experimental groups) created as a result of PSM procedure

REFERENCE GROUP:

RESEARCHERS NOT COLLABORATING

WITH ENTERPRISES $(\mathrm{N}=5806)$ GENDER

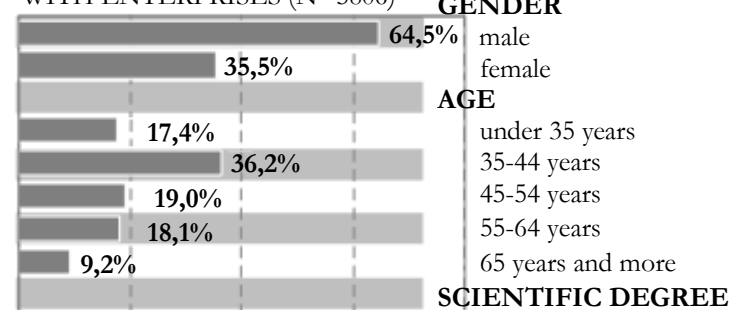

\section{$65,5 \%$}

\begin{tabular}{|c|c|c|}
\hline $19,5 \%$ & \\
\hline $13,3 \%$ & \\
\hline & & \\
\hline
\end{tabular}

$9,3 \%$

\begin{tabular}{|c|c|}
\hline $16,4 \%$ & \\
\hline $3,9 \%$ & \\
\hline $4,1 \%$ & \\
\hline $6,4 \%$ & \\
\hline $5,3 \%$ & \\
\hline $9,2 \%$ & \\
\hline
\end{tabular}

$15,1 \%$

\section{$4,8 \%$}

$8,4 \%$

$11,8 \%$

$5,2 \%$
Dr hab.

Prof.

SCIENTIFIC DISCILPLINE humanities

economic and social science science

biological science

natural science

medical science

agricultural science

mechanics, technical engineering

material engineering

chemical science

electronics, communication and IT

mining and energy studies

$80 \%$

EXPERIMENTAL GROUP:

RESEARCHERS COLLABORATING WITH

ENTERPRISES $(\mathrm{N}=5806)$

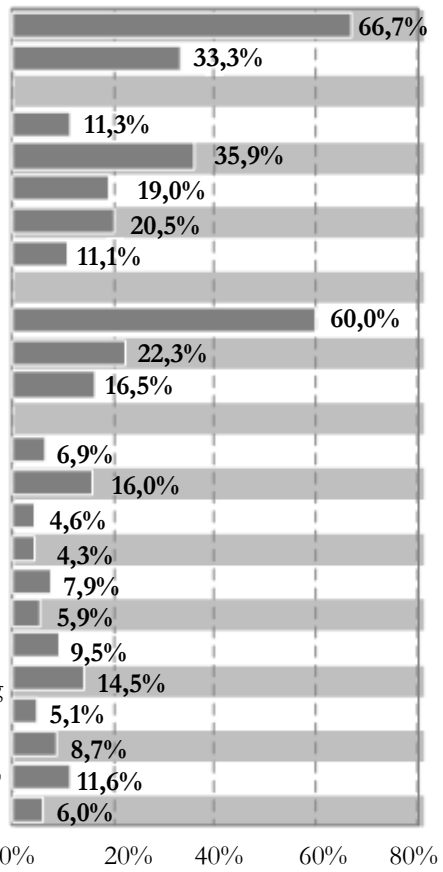

Source: author's own work.

Results obtained from the analyses of research performance indicate differences in publication and peer-reviewing performance between academics collaborating and non-collaborating with business sector. In particular researchers working with enterprises on finding solutions on technical issues are more productive in both publications and peer-reviewing activities.

PSM technique used for analyses enabled to exclude from observed positive impact of collaboration activity on academic performance, the intermediary effect of age, gender, scientific degree, scientific discipline and affiliation. 
CHART 3.

\section{Impact of business collaboration on publication productivity and peer-to peer reviewing performance (net effect)}

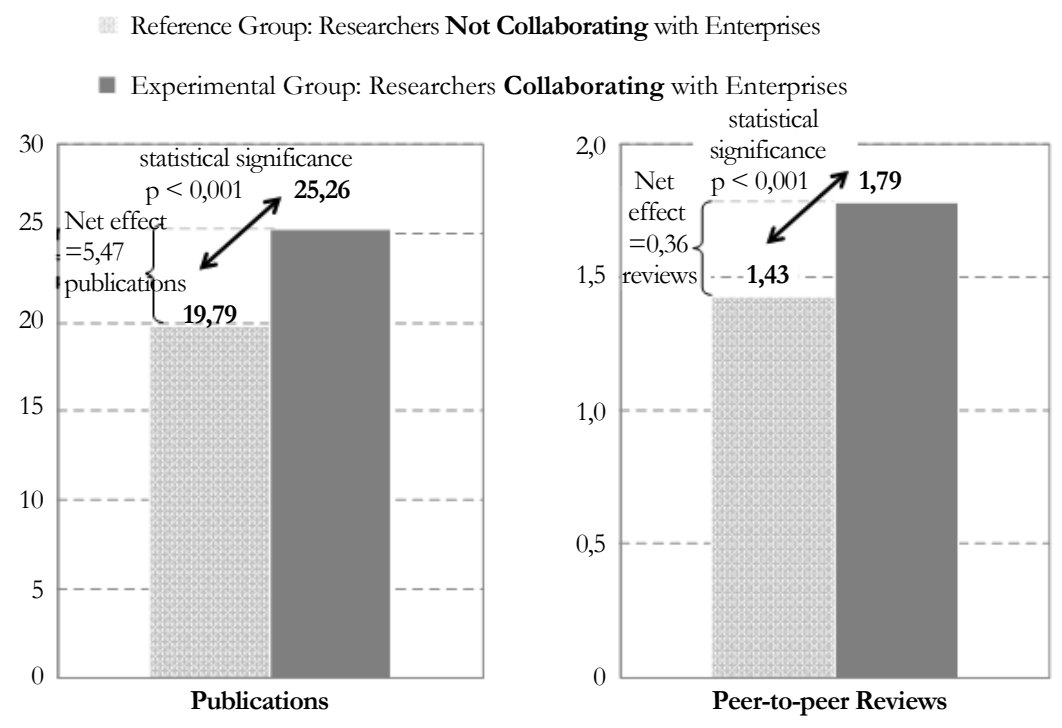

Source: author's own work.

Indicated and presented on Chart 3 differences in averages numbers of publications and peer-reviews per individuals are statistically significant $(\mathrm{t}=-10.171 ; \mathrm{df}=5805$; $\mathrm{p}<0.001$ for publications and $\mathrm{t}=-4.068 ; \mathrm{df}=5805 ; \mathrm{p}<0.001$ for peer-reviewing performance).

Researchers taking active part in collaboration with business sector are prone to prepare more publications than scientists focusing only on scientific performance. Difference in average levels of publications per individual between experimental and reference group is significant. Scientists engaged in projects with enterprises encounter the average of 25.26 publications, while academics working solely on scientific issues publish about 19.79 research papers. Disparity in average numbers accounts for 5.47 publications, which covers $21.65 \%$ of publication productivity for business-oriented researchers. Scientists engaged in cooperation with enterprises are expected to publish $27.64 \%$ more than these with no experience in business.

Research results suggest that academics cooperating with entrepreneurs are expected to engage more in peer-reviewing activity in scientific community than academics not cooperating with companies. Difference between average numbers of peer-to-peer reviews between experimental and reference groups is not great in numbers. However, from the statistical point of view, it is significant. Business-oriented researchers are asked to prepare on average 1.79 evaluations of their peers' research work, while researchers 
focusing solely on scientific activity prepare on average 1.43 reviews. Disparity does not refer to total numbers but is still significant.

\subsection{Stirling Index Analysis}

The values of the Stirling Index were calculated separately for each of research professionals recorded in the database of 2076 cases. Results of the average SI values for individuals with reference to groups of scientists collaborating and not-collaborating with enterprises is given in the Table 2 .

TABLE 2.

Collaboration with enterprises and indisciplinarity performance of academics

\begin{tabular}{|c|c|}
\hline $\begin{array}{c}\text { Question: } \\
\text { Do you have experience in } \\
\text { collaboration with } \\
\text { enterprises on solving } \\
\text { technical issues? }\end{array}$ & Stirling Index \\
\hline No $(\mathrm{N}=842)$ & \\
Yes $(\mathrm{N}=1234)$ & 0.092 \\
Total $(\mathrm{N}=2076)$ & 0.071 \\
Significance level $(\mathrm{p}<0,05)$ & 0.080 \\
\hline
\end{tabular}

Source: author's own work.

It is visible that research interdisciplinarity level measured by the SI is significantly higher among academics having experience in working with enterprises over technical solutions than within the group of academics focusing solely on research performance. These results suggest that business-oriented scientists are prone to be more interdisciplinary.

\section{Conclusions}

Results of the study strongly suggest that academics with business orientation are likely to enhance their recognition within the scientific community. Scientists that join research performance and collaboration with enterprises are prone to prepare more scientific publications than academics focusing solely on research performance.

At the same time, competencies and knowledge of business-oriented research professionals are appreciated by academic society. Scientists with experience in collaboration with business sector tend to be asked more frequently to evaluate research work performed by other academic peers.

The observed tendency is contrary to common beliefs that valuable scientific studies might only be an outcome of purely scientific performance. With reference to conducted study, to become the prestigious scientist one needs to have experience in business cooperation and understands needs of entrepreneurs. It is suggested that significant 
research is an outcome of interdisciplinary activity of individual academics joining purely scientific issues and cooperating with business sector.

Moreover, knowledge obtained from research performance should be at some point adaptable to solve technical issues of enterprises. Study gives the evidence that cooperation between academics and entrepreneurs over technical problems do not concern only research professionals from technical and engineering sciences. It is indicated that business-oriented researchers from each of enumerated scientific disciplines are prone to make greater number of publications and can be invited for peer-to-peer review more often than scientists not interested in academic-business cooperation.

As visible in the research, interdisciplinarity in scientific performance is correlated with the business orientation of research professionals. Academics cooperating with enterprises over solutions to technical problems are more interdisciplinary in their research than researchers focusing solely on pure scientific studies. Knowledge and competencies acquired by researchers from different scientific disciplines might be of advance for potential business collaboration. At the same time cooperation with enterprises might give research professionals an opportunity to start field studies in new, formerly undiscovered discipline.

Finally, it is important to underline that visible presence of Polish research professionals eager to work for commercialization of their knowledge resources suggests the change in the mentality of Polish scientific communities. Academic society seems to start understanding the knowledge paradigm development toward creation of more applied knowledge in business and industry sectors.

\section{References}

Agrawal A. 2001 University-to-Industry Knowledge Transfer: Literature Review and Unanswered Questions, "International Journal of Management Reviews", 3.

Bird B. J., Allen D. N. 1989 Faculty Entrepreneurship in Research University Environments, "The Journal of Higher Education", Vol. 60, No. 5 (Sep. - Oct.).

Clark B. R. 1998 Creating Entrepreneurial Universities: Organisational Pathways of Transformation, published for the IAU Press by Pergamon Press.

Collier A., Gray B. 2010 The Commercialisation of University Innovations - A Qualitative Analysis of the New Zealand Situation, Centre for Entrepreneurship School of Business University of Otago, Research report.

Cook T., Dwek T. R., Blumberg B., Hockaday T. 2008 Commercialising University Research: Threats and Opportunities - The Oxford Model, "Capitalism and Society". Vol. 3, Is. 1, Article 4.

D’Este P., Perkmann M. 2011 Why Do Academics Engage with Industry? The Entrepreneurial University and Individual Motivations, "The Journal of Technology Transfer", 36(3).

Duberley J., Cohen L., Leeson E. 2007 Entrepreneurial Academics: Developing Scientific Careers in Changing University Settings, "Higher Education Quarterly", Vol. 61, No. 4, October.

Etzkowitz H. 2008 The Triple Helix. University - Industry - Government, Innovation in Action, Routledge, London. 
Etzkowitz H., Leydesdorff L. 2000 The Dynamics of Innovation: From National System and "Mode 2" to a Triple Helix of University-Industry-Government Relations, "Research Policy' 29.

Etzkowitz H. 2004 The Evolution of the Entrepreneurial University, "Int. J. Technology and Globalisation", Vol. 1, No.1.

Gibb A., Haskins G., Robertson I. 2013 Leading the Entrepreneurial University: Meeting the Entrepreneurial Development Needs of Higher Education Institutions, [in:] Universities in Change, Springer, New York.

Gibb A., Haskins G., Hannon P., Robertson I. 2012 Leading the Entrepreneurial University: Meeting the Entrepreneurial Development Needs of Higher Education (2009, updated 2012).

Hagen S. 2008 From Tech Transfer to Knowledge Exchange: European Universities in the Marketplace, Wenner-Gren International Series, 84.

Higher Education Act 2005, Journal of Laws 2012, Item. 572, as amended.

Kijeńska-Dąbrowska I. 2011 The Roles of Public R\&D Entities [in:] Modern Society Innovative Potential in the Dynamic Knowledge-Based Economy, Konwledge and Innovation Institute, Cracow, pp.72-97.

Kim Y., Kim W., Yang T. 2012 The Effect of the Triple Helix System and Habitat on Regional Entrepreneurship: Empirical Evidence from the US, "Research Policy", 41(1).

Knapińska A., Tomczyńska A. 2013 Competences of Polish Scientists as a Contribution to the Success of Innovation Research and Development Projects, [in:] Innovations and Knowledge Commercialization. Cooperative Resources, Integrated Science and Business, Centrum Transferu Technologii Uniwersytetu Lódzkiego, Łódź.

Lehrera M., Nell P., Gärber L. 2009 A National Systems View of University Entrepreneurialism: Inferences from Comparison of the German and US Experience, "Research Policy", 38.

Leydesdorff L., Meyer M. 2003 The Triple Helix of University - Industry - Government Relations, "Scientometrics", Vol. 58, No. 2.

Leydesdorff L., Rafols I. 2011 Indicators of the Interdisciplinarity of Journals: Diversity, Centrality, and Citations, "Journal of Informetrics", 5.

Meyer L. H., Evans I. M. 2007 Supporting Academic Staff: Meeting New Expectations in Higher Education without Compromising Traditional Faculty Values, "Higher Education Policy", Vol. 20.

Mohrman K. et al. 2008 The Research University in Transition: The Emerging Global Model, "Higher Education Policy" 21.

Mosey S., Noke H., Binks M. 2012 The Influence of Human and Social Capital upon the Entrepreneurial Intentions and Destinations of Academics, "Technology Analysis \& Strategic Management", 24(9).

Philpott K., Dooley L., O’Reilly C., Lupton G. 2011 The Entrepreneurial University: Examining the Underlying Academic Tensions, "Technovation”, 31(4).

Science Funding Act 2010, Journal of Laws 96, Item 615, as amended.

Van Looy B., Landoni P., Callaert J., van Pottelsberghe B., Sapsalis E., Debackere K. 2011 Entrepreneurial Effectiveness of European Universities: An Empirical Assessment of Antecedents and Trade-offs, "Research Policy" 40(4).

Van Vught F., Kaiser F., File J. M., Gaethjens C., Peter R., Westerheijden F. 2010 U-Map: The European Classification of Higher Education Institutions, CHEPS, Enschede, Netherlands. 
APPENDIX 1.

National Science Centre Panels of Disciplines

\begin{tabular}{|c|c|c|c|}
\hline & & NSC Panel name & Disciplines \\
\hline \multirow{6}{*}{ 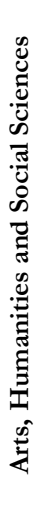 } & HS1 & $\begin{array}{l}\text { Fundamental questions } \\
\text { of human existence and } \\
\text { the nature of reality }\end{array}$ & philosophy, cognition, religious studies, theology \\
\hline & HS2 & Culture & $\begin{array}{l}\text { literary theory and comparative literature, history of literature, linguistics, } \\
\text { library science, cultural studies, arts, architecture }\end{array}$ \\
\hline & HS3 & $\begin{array}{l}\text { The study of the human } \\
\text { past }\end{array}$ & history, archaeology, ethnology, cultural anthropology \\
\hline & HS4 & $\begin{array}{l}\text { Individuals, institutions, } \\
\text { markets }\end{array}$ & $\begin{array}{l}\text { economics, finance, management, demography, social and economic } \\
\text { geography, urban studies }\end{array}$ \\
\hline & HS5 & Norms and governance & law, political studies, regional and social policies \\
\hline & HS6 & $\begin{array}{l}\text { Human nature and } \\
\text { human society }\end{array}$ & psychology, pedagogy/education studies, sociology \\
\hline \multirow{10}{*}{ 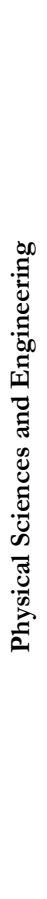 } & ST1 & Mathematics & $\begin{array}{l}\text { all areas of mathematics, pure and applied, plus mathematical foundations of } \\
\text { computer science, mathematical physics and statistics }\end{array}$ \\
\hline & ST2 & $\begin{array}{l}\text { Fundamental } \\
\text { constituents of matter }\end{array}$ & particle, nuclear, plasma, atomic, molecular, gas and optical physics \\
\hline & ST3 & $\begin{array}{l}\text { Condensed matter } \\
\text { physics }\end{array}$ & structure, electronic properties, fluids, nanosciences \\
\hline & ST4 & $\begin{array}{l}\text { Physical and analytical } \\
\text { chemical sciences }\end{array}$ & $\begin{array}{l}\text { analytical chemistry, theoretical methods in chemistry, physical } \\
\text { chemistry/chemical physics }\end{array}$ \\
\hline & ST5 & Materials and synthesis & $\begin{array}{l}\text { materials synthesis, structure-properties relations, functional and advanced } \\
\text { materials, molecular architecture, organic chemistry }\end{array}$ \\
\hline & ST6 & $\begin{array}{l}\text { Computer science and } \\
\text { informatics }\end{array}$ & $\begin{array}{l}\text { informatics and information systems, computer science, scientific computing, } \\
\text { intelligent systems }\end{array}$ \\
\hline & ST7 & $\begin{array}{l}\text { Systems and } \\
\text { communication } \\
\text { engineering }\end{array}$ & electronic, communication, optical and systems engineering \\
\hline & ST8 & $\begin{array}{l}\text { Products and processes } \\
\text { engineering }\end{array}$ & $\begin{array}{l}\text { product design, process design and control, construction methods and } \\
\text { engineering, material engineering, power units and systems }\end{array}$ \\
\hline & ST9 & $\begin{array}{l}\text { Astronomy and space } \\
\text { research }\end{array}$ & $\begin{array}{l}\text { astrophysics/astrochemistry/astrobiology; solar system; stellar, galactic and } \\
\text { extragalactic astronomy, planetary systems, cosmology, space science, } \\
\text { instrumentation }\end{array}$ \\
\hline & ST10 & Earth system science & $\begin{array}{l}\text { Earth science, atmosphere and climate, geochemistry, geodesy, geophysics, } \\
\text { physical geography, geoinfomatics, planetary geology, pedology, mining, } \\
\text { chemical and physical oceanology, changes and protection of natural } \\
\text { environment }\end{array}$ \\
\hline \multirow{2}{*}{ 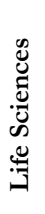 } & NZ1 & $\begin{array}{l}\text { Molecular biology, } \\
\text { structural biology, } \\
\text { biotechnology }\end{array}$ & $\begin{array}{l}\text { molecular biology, biochemistry, biophysics, structural biology, biochemistry } \\
\text { of signal transduction }\end{array}$ \\
\hline & NZ2 & Genetics, genomics & $\begin{array}{l}\text { genetics, molecular genetics, genomics, proteomics, metabolomics, } \\
\text { bioinformatics, computational biology, systems biology and genetic } \\
\text { epidemiology }\end{array}$ \\
\hline
\end{tabular}




\begin{tabular}{|c|c|l|l|}
\hline NZ3 & $\begin{array}{l}\text { Cellular and } \\
\text { developmental biology }\end{array}$ & cell biology, developmental biology, ageing biology, neurobiology \\
\hline NZ4 & $\begin{array}{l}\text { Biology of tissues, } \\
\text { organs and organisms }\end{array}$ & $\begin{array}{l}\text { morphology and functions of animal's and human's systems, organs and } \\
\text { organisms, experimental medicine, basics of neurology }\end{array}$ \\
\hline NZ5 & $\begin{array}{l}\text { Human and animal } \\
\text { noninfectious diseases }\end{array}$ & mechanisms, diagnosis and treatment of diseases, poisonings and injuries \\
\hline NZ6 & $\begin{array}{l}\text { Human and animal } \\
\text { immunology and } \\
\text { infection }\end{array}$ & $\begin{array}{l}\text { Diagnostic tools, } \\
\text { therapies and public } \\
\text { health }\end{array}$ & $\begin{array}{l}\text { immunity, immune disorders, immunotherapy, infectious and invasive } \\
\text { diseases, microbiology, transplantology, allergology } \\
\text { eharmacology, clinical medicine, regenerative medicine, medical ethics }\end{array}$ \\
\hline NZ8 & $\begin{array}{l}\text { Evolutionary and } \\
\text { environmental biology }\end{array}$ & $\begin{array}{l}\text { evolution, ecology, population biology, biodiversity, biogeography } \\
\text { Applied life sciences and } \\
\text { biotechnology }\end{array}$ & $\begin{array}{l}\text { agricultural, animal, fishery, forestry and food sciences; biotechnology, genetic } \\
\text { engineering, synthetic and chemical biology, industrial biosciences, } \\
\text { environmental biotechnology and remediation }\end{array}$ \\
\hline NZ9
\end{tabular}

Source: https://www.ncn.gov.pl/finansowanie-nauki/panele-ncn?language=en. 